\title{
MAŁŻEŃSTWA MIESZANE I JAK SOBIE W NICH RADZIĆ WEDŁUG „TABLICY MAŁŻEŃSKIEJ” 1P 3,1-7. ZA CZY PRZECIW TRADYCJI PAWŁOWEJ?
}

Współczesne media często nagłaśniają historie związane z przemocą, u podłoża której niejednokrotnie leży religia. Dotyczy ona również małżeństw, a stroną pokrzywdzoną często bywają kobiety. Nietrudno odnaleźć w bogatym świecie newsów opowieści o związkach aranżowanych, o przemocy, wykorzystywaniu, a nawet zabójstwach - wszystko w imię realizowania promowanego w niektórych religiach i ideologiach „poddaństwa”. Za sprawą Biblii wizja „,poddanej żony" zakorzeniła się również w myśli chrześcijańskiej - i to wyjątkowo mocno. Chętnie propagowali ją Ojcowie Kościoła, odczytując i komentując kłopotliwe teksty nader literalnie. ${ }^{1}$ Współcześnie poddanie żony stało się kością niezgody między ścierającymi się ze sobą środowiskami feministycznymi i konserwatywnymi, a głównym winowajcą waśni stał się św. Paweł, w którego pismach nietrudno odnaleźć teksty, uchodzące już nie tylko za antykobiece, ale, wedle niektórych badaczy/ek, epatujące osobistą wrogością Apostoła Narodów względem płci pięknej. Pawła nietrudno jest obronić przed oskarżeniami o mizoginizm, sięgając choćby po cały passus Rz 16,

1 Przykładem poddania żony jest matka św. Augustyna, Monika, która mimo domowej przemocy godziła się na swój los, licząc na nawrócenie męża. Biskup Hippony tak opisuje jej postawę „Moja matka (...) im mówiła, że skoro wysłuchały niegdyś umowy małżeńskiej, powinny wiedzieć, iż stały się służebnicami swych mężów; niechże teraz, pamiętając o swej roli, nigdy się zuchwale im nie sprzeciwiają"; Św. A u g u s t y n, $W y$ znania IX,9, tłum. Z. K u b i a k, Kraków 2009, s. 260-261. Los chrześcijańskich żon Caryn Reeder porównuje do sytuacji niewolników. Zauważa w pismach Augustyna wyraźne nawiązania do 1P 3,1-6, zestawiając równocześnie ów passus z paralelnym tekstem o niewolnikach z 1P 2,18-25; C. R e e d e r, 1 Peter 3:1-6: Biblical Authority and Battered Wives, Bulletin for Biblical Research 25 (2015) nr 4, s. 519-520. 
a w listach apostoła wskazać można przynajmniej 14 kobiet, z którymi współpracował, i dlatego to nie pismo głównego winowajcy biblijnego dyskursu antykobiecego stanie się przedmiotem zainteresowania, ale tekst przypisywany samemu Piotrowi. ${ }^{2}$

Tzw. tablice domowe (niem. Haustafeln) obecne są w kilku księgach Nowego Testamentu (Ef 5,22-6,9; Kol 3,18-4,1; Tt 2,1-10 oraz 1P 2,13-3,7). Już pobieżna analiza pozwala dostrzec w obrębie gatunku „tablic domowych” przynajmniej dwie odrębne tradycje: Pawłową i Piotrową. Tym, co jest wspólne dla „tablic Pawłowych”, jest kolejność podejmowanych tematów: od porad dla mężów i żon, przez problem relacji dzieci oraz ojców, po wzajemny stosunek niewolników i ich panów. Tablica Piotrowa z jednej strony pomija temat wzajemnych stosunków dzieci i rodziców, z drugiej rozbudowuje tekst o napomnienia dotyczące relacji wewnątrz szerzej pojętej rodziny - rodziny ludzkiej (1P 2,15-17). Feldmeier zaznacza, że to nie

2 Autorstwo Piotra w przypadku 1P znajduje zarówno przeciwników, jak i zwolenników, nawet jeśli sam autor listu przyznaje, że był świadkiem męki Chrystusa (1P 5,1), a Ojcowie Apostolscy nie mają większych wątpliwości, że chodzi o samego Kefasa. Autorstwo kwestionuje się głównie na podstawie przekraczającego możliwości galilejskiego rybaka stylu oraz milczenia na temat tego tekstu w kanonie Muratoriego oraz u Marcjona. Obecnie za najprawdopodobniejszego autora 1P uznaje się wspólnego ucznia Pawła i Piotra - Sylwana (1P 5,12; zob. 2 Kor 1,19; 1Tes 1,1; 2Tes 1,1), co tym samym uzasadnia obecność Pawłowych inspiracji (zwłaszcza z Rz i Ef). J. Z a ł ę s k i, Obraz kobiety w listach Nowego Testamentu, Ząbki 2007, s. 238-239; Listę wspólnych tematów Pierwszego Listu Piotra i listów Pawłowych zob. w: J. H. E 11 i o t t, 1 Peter. A New Translation with Introduction and Commentary, The Anchor Bible 37b, New York-London-Toronto 2000, s. 22nn. Warto wspomnieć, że autor listu wymienia również imię Marka, przez co on także stał się jednym trzech głównych kandydatów na autora; zob. tamże, s. 127-130. Posługiwać się zatem będziemy terminologią sugerowaną przez Janusza Kręcidło, który zauważa, że mówienie o „tradycji Piotrowej” czy „kręgu Piotrowym” zwalnia nas z dodatkowych dociekań na temat Piotrowego autorstwa i pozwala mówić o Piotrze jako autorze (bezpośrednim lub pośrednim); por. J. K r ę c i d ł o, Sytuacja społeczna i religijna adresatów Pierwszego Listu Piotra, w: W. C h ro s to w s k i, B. Str z a ł k ow $\mathrm{s} \mathrm{k}$ a (red.), Patrzmy na Jezusa, który nam w wierze przewodzi (Hbr 12,2). Księga pamiątkowa dla Księdza Profesora Jana Łacha $w$ 85. rocznicę urodzin, Warszawa 2012, s. 337n. 
kolejność odróżnia tablice Piotrowe od Pawłowych, ale ich orientacja na zewnętrzne oddziaływanie chrześcijaństwa $-\mathrm{z}$ akcentem na konieczność misji i apologii. ${ }^{3}$ Warto zauważyć, że o ile u Pawła kodeksy domowe znalazły się pod koniec listów (1Kor i Ef), o tyle w Pierwszym Liście Piotra problem relacji w gospodarstwie domowym umieszczony został w samym centrum listu. Wspólną osią dla wszystkich tablic domowych jest jednak tzw. tablica małżeńska. Wydaje się, że zagadnienia dotyczące uporządkowania relacji damsko-męskich uznane zostały za palące zarówno przez środowisko Pawłowe jak i Piotrowe, choć u podstaw zajęcia się nimi leżą zgoła odmienne przesłanki.

Niniejszy tekst jest próbą interpretacji „tablicy małżeńskiej” w Pierwszym Liście Piotra we właściwym jej kontekście oraz ewentualnego zestawienia jej z parenezą Pawłową skierowaną do anatolijskich Efezjan (Ef 5,21-33). ${ }^{4}$ Dokonamy analizy diachronicznej-egzegezy tekstu w jego kontekście społeczno-kulturowym wraz z wychwyceniem treści, które pozwolą uznać „tablicę Piotrową” za wciąż aktualną i cenną dla współczesnego człowieka w kontekście współczesnego Zachodu ${ }^{5}$ - wszak to właśnie zakłada natchnienie tekstu.

\section{„Tablice małżeńskie”}

„Tablice małżeńskie” stanowią jeden z podstawowych elementów „tablic domowych”, gatunku literackiego wyodrębnionego przez samego Lutra. „Tablice domowe” znalazły wiele realizacji w literaturze pogańskiej - spisuje je Arystoteles (Ekonomik), Platon (Republika),

3 R. Feld me i e r, The First Letter of Peter. A Commentary on the Greek Text, Waco 2008, s. 155.

4 Tablicy tej poświęcony został artykuł: A. R a m b i e r t - K w a ś n i e w s k a, „Kobiety (...) mają być poddane, jak to Prawo nakazuje” (1 Kor 14,34). Krytyka feministycznej lektury Ef 5, 21-33, Family Forum 4/2014, s. 71-88.

5 Poczynić należy uwagę, że w niektórych zakątkach naszego globu sytuacja kobiety niewiele odbiega od tej, którą nakreśla autor 1P - mówiąc „niewiele”, nie zawsze mamy, niestety, na myśli, że jest ona mimo wszystko lepsza. 
Ksenofont (Ekonomik) i inni. ${ }^{6}$ Ze względu na kłopotliwe treści, w ramach rekonstrukcji sytuacji starożytnego oikos, wiele miejsca poświęca się im we współczesnym piśmiennictwie naukowym. ${ }^{7}$ Popularność „tablic domowych” wśród pisarzy greckich i łacińskich wpłynęła znacząco na błędne postrzeganie owego zagadnienia wśród współczesnych badaczy w tekstach nowotestamentowych. Szczęśliwie ów błąd anachronizmu został dostrzeżony i zaprzestano przykładania klasycznych tekstów, a zarazem kontekstów kulturowych np. Stagiryty z (IV w. przed Chr.) do tekstów biblijnych, skierowanych do wspólnot anatolijskich w I w. po $\mathrm{Chr}^{8}{ }^{8}$ Owa chronologiczna precyzja jest o tyle ważna, że sytuacja kobiet w okresie rzymskim diametralnie odbiegała od tej, którą prezentuje Arystoteles, uznający kobietę za majątek ruchomy mężczyzny.

Status kobiety w epoce Nowego Testamentu uległ znacznej poprawie - na tyle istotnej, że mówi się o tym okresie w słowach znanych raczej ze współczesnego dyskursu, jako o czasie emancypacji kobiet.

6 Gospodarstwem domowym szerzej zajęli się również współcześni względem Nowego Testamentu Seneka (w Listach moralnych), Plutarch (Zalecenia matżeńskie) oraz Dion Chryzostom; zob. K. H. J o b e s, 1 Peter, Baker Exegetical Commentary on the New Testament, Grand Rapids 2005, s. 181.

7 Z literatury poświęconej Haustafeln warto wspomnieć m.in. J.P. H e r i n g, The Colossian and Ephesian Haustafeln in Theological Context: An Analysis of their Origins, Relationship, and Message, American University Studies, VII, New York 2007; J. W o y k e, Die neutestamentlichen Haustafeln: Ein kritischer und konstruktiver Forschungsüberblick, SBS 184, Stuttgart 2000; R. D u d r e y, ,Submit Yourself to One Another": A Socio-Historical Look at the Household Code of Ephesians 5:15-6:9, Restoration Quarterly 41/1999, s. 27-44; M. G i e 1 e n, Tradition und Theologie neutestamentlicher Haustafelethik: Ein Beitrag zur Frage einer christlichen Auseinandersetzung mit gesellschaftlichen Normen, BBB 75, Frankfurt 1990; E. S c h w e i z e r, Die Weltlichkeit des Neuen Testaments. Die Haustafeln, w: H. D o n n e r i in. (red.), Beiträge zur alttestamentlichen Theologie. Festschrift W. Zimmerli, Göttingen 1977, s. 397-413; D.W. B r o w n, Revolutionary Subordination. A Bible Study of the Haustafeln, Brethren Life and Thought 20/1975, s. 159-164.

8 Zob. np. S. W. H e n d e r s o n, Taking Liberties with the Text. The Colossians Household Code As Hermeneutical Paradigm, Interpretation 60(2006) nr 4, s. 423n.; A. $\mathrm{S} t \mathrm{and}$ h a r t ing e r, The Origin and Intention of the Household Code in the Letter to the Colossians, JSNT 79 /2000, s. 118nn. 
Nastąpiło przejście od małżeństwa in manum (cum manu), gdy kobieta przekazywana była mężowi i ciążył na niej obowiązek przejęcia religii mężczyzny, do sine manu, w ramach którego pozostawała właściwie osobą obcą dla męża, jego rodziny i własnych dzieci, a jej opiekunem wciąż był ojciec. W tym drugim przypadku nie musiała przejmować kultu męża oraz zachowywała większą wolność oraz możliwość odwrotu, gdyby jej mąż okazał się agresywny. ${ }^{9}$ Ważnym novum była również możliwość dziedziczenia przez kobiety oraz liberalizacja zasady kyrieia, która podporządkowywała przedstawicielki płci pięknej kyriosom, czyli panom. Wedle Krystyny Stebnickiej inskrypcje anatolijskie dowodzą ponadto, że kobiety żydowskie częstokroć piastowały w gminach funkcje przywódcze, były liderkami, fundatorkami i wchodziły w poczet starszyzny. ${ }^{10}$ Wydawałoby się, że poprawa życiowej sytuacji kobiet wprowadzała większą swobodę również na płaszczyźnie religijnej. Co się jednak działo, gdy religię kobiety uznawano za religio illicita, a później nawet superstitio (wyjątkowo niebezpieczny zabobon), ${ }^{11}$ a jej mąż nie podzielał i nie rozumiał jej wierzeń?

9 Reeder zaznacza jednak, że ewentualne zaangażowanie kobiety w inne kulty było piętnowane przez autorów greckich i rzymskich z obawy przed kobiecą rozwiązłością i pijaństwem. Autorka powołuje się w tym miejscu teksty: filozofki Fintys, Katona Agr. 143 czy Apulejusza Metam. 9,14 . Wspomina również o Cyceronie, który uważał jedność kultu (eisdem uti sacris) za czynnik spalający małżeństwo (Off. 1,54-55; Amic. 23); C. R e e d e r, 1 Peter 3:1-6, s. 525-526.

10 K. S t e b n i c k a, Tożsamość diaspory. Żydzi w Azji Mniejszej okresu cesarstwa, Warszawa 2011, s. 56-66; Wobec powyższego bezkrytyczne powielanie wizji uprzedmiotowienia kobiety na przełomie er i wliczania jej w poczet majątku ruchomego męża (np. za N. H i 11 y e r, 1 and 2 Peter, Jude, New International Biblical Commentary, Peabody 1994, s. 97), by podkreślić nowość nauczania autorów nowotestamentowych, należy bezwzględnie korygować.

1 Gdy judeochrześcijanie odżegnali się od judaizmu, by nie płacić podatku zwanego Fiscus Iudaicus, uznano ich po 96 r., czyli jeszcze za panowania Domicjana, za praktykujących religio illicita - „religię zakazaną”. Był to pierwszy krok ku prześladowaniom. Podobnie za czasów Nerwy uznano chrześcijaństwo za superstitio, czyli zabobon, co przypieczętowało ich tragiczną sytuację; M. R o s i k, Kościół a Synagoga (30-313 po Chr.). Na rozdrożu, Wrocław 2016, s. 289-290. Zmiana 


\section{Klucze do Piotrowej „tablicy malżeńskiej”? (1P 2,12)}

Jak zaznaczyliśmy już we wstępie, „tablica małżeńska” w liście Piotrowym odbiega od tych, które zapisane zostały w listach Pawła. Jej różnica nie kryje się jedynie w przesłaniu - wyraźnym wezwaniu kobiet do podporządkowania mężom, ale przede wszystkim w okolicznościach, których dotyczy. Rozpracowuje ona bowiem temat, z którym Paweł rozprawia się w tzw. przywileju Pawłowym $(1 \text { Kor } 7,15)^{12}$ - problem małżeństw mieszanych. Czym różni się kontekst tekstu Piotrowego, skoro zarówno Pierwszy List Piotra jak i List do Efezjan skierowane zostały do wspólnot anatolijskich (zob. 1P 1,1; Ef 1,1)? Wydaje się, że tym, co uległo zmianie, były wspomniane przez autora Pierwszego Listu Piotra, narastające prześladowania, które badacze, głównie opierając się na testimonium Pliniusza Młodszego (Ep. 10,96-97), identyfikują z czasami cesarzy Domicjana (ok. 96 r.) lub nawet Trajana (98-112). ${ }^{13}$ Choć nie ma pewności co do dokładnej datacji Piotrowego tekstu, proponowane (oczywiście z uznaniem pseudonimiczności listu) np. przez Johna H. Elliotta terminus post quem (73 r. po Chr.) oraz terminus ante quem (92 r. po Chr.) wciąż sytuują go w kontekście prześladowań. ${ }^{14}$ Kontekst historyczny jest więc pierwszym kluczem interpretacyjnym.

Wedle niektórych egzegetów punktem wyjścia jest w. 2,12, w którym Piotr podaje klucz - dla nas już drugi - do zrozumienia dalszej części parenezy: „Wasze zachowanie wśród pogan niech będzie szla-

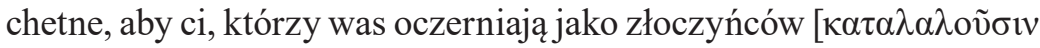

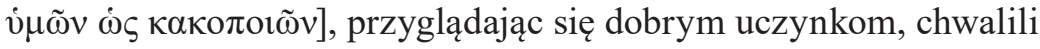

statusu chrześcijaństwa odbiła się z pewnością na relacjach w wielu mieszanych małżeństwach i całych rzymskich rodach, w których poganie żyli pod jednym dachem z chrześcijanami.

12 Więcej o tzw. przywileju Pawłowym w: S. J a n k o w s k i, ,, Co Bóg złączył...”. Geneza i znaczenie klauzul Mateuszowych. Studium egzegetyczno-historyczne, Rozprawy i Studia Biblijne 46, Warszawa 2016, s. 267-272.

13 J. Z a ł ę s k i, Obraz kobiety w listach Nowego Testamentu, s. 239; K. H. J o b e s, 1 Peter, s. 8.

14 J. H. E 11 i ot t, 1 Peter, s. 135-138. 
Boga w dniu nawiedzenia" (1P 2,12). Z wersetu tego jasno wynika, że mamy do czynienia z dwiema grupami - pierwszą są chrześcijanie, którzy żyją wśród pogan, drugą poganie, którzy ich oczerniają. ${ }^{15}$ Zadaniem chrześcijan znajdujących się w sytuacjach przemocowych

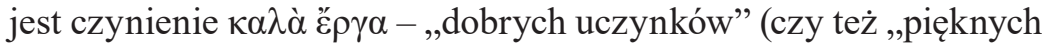
dzieł"), które skłoniłyby krzywdzicieli do nawrócenia, a w rezultacie doprowadziły do życia wiecznego w dniu Pańskim, zwanym tu $\dot{\eta} \mu \varepsilon \dot{\rho} \rho \alpha \dot{\varepsilon} \pi \imath \kappa \kappa \pi \tilde{\eta} \varsigma$ - „dniem nawiedzenia”. ${ }^{16}$ Skąd czerpiemy wiedzę o tym, że autor listu odnosi się w „tablicy małżeńskiej” do przemocy domowej? Po pierwsze, jej obecność implikuje porównanie żon do niewolników, dla których niemoralni ( $\sigma \kappa o \lambda$ iós) właściciele mogą być źródłem cierpień ( $\pi \alpha ́ \sigma \chi \omega$ w w. 2,19-20). Po drugie, z przyrównania cierpień niewolników i żon do męki Chrystusa (2,21-23); po trzecie, wreszcie, z w. 3,6, w którym jest mowa o zastraszaniu (a nawet o ży-

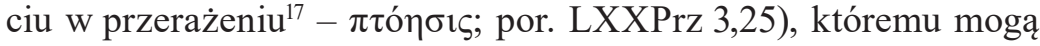
zostać poddane przez własnych współmałżonków. Warto zwrócić jeszcze uwagę na pewną standaryzację postaw - stroną krzywdzącą jest w pouczeniu Piotrowym strona pogańska, krzywdzoną - chrześcijańska. Biorąc pod uwagę ukute przez Pawła katalogi cnót i wad (choćby z Ga 5), można uznać, że w apostolskim wyobrażeniu sytuacja odwrotna byłaby nie do pomyślenia. ${ }^{18}$

15 Stanisław Hałas zauważa, że w wielu miejscach 1P możemy znaleźć dowody na wszechobecność przemocy słownej, na którą narażeni byli chrześcijanie. Mówi się o oczernianiu $(2,12 ; 3,16)$, szyderstwach $(3,16)$, oszczerstwach $(4,4)$, złorzeczeniach (4,14), złych słowach (3,9nn.), ubliżaniu $(2,23 ; 3,9)$ i podstępie w mowie $(2,22 ; 3,10)$; S. H a ł a s, Pierwszy List św. Piotra, NKB 17, Częstochowa 2007, s. 50. Dostrzegamy zatem rosnące w społecznościach anatolijskich napięcia społeczne na płaszczyźnie religijnej, które w linii prostej prowadziły do prześladowań.

16 Termin غ̇лıбколи́ wydaje się konotować treści eschatologiczne, choć np. Łukasz posługuje się nim w kontekście życia Chrystusa, które stanowiło formę Bożego „nawiedzenia” (Łk 19,44).

17 T. M u r a o k a, A Greek-English Lexicon of the Septuagint, Louvain-Paris-Walpole 2009, s. 606; Termin ten spokrewniony jest z $\pi \tau$; archimedes.fas.harvard.edu (dostęp: 4 XI 2017).

18 Co prawda nieskłonność do stosowania przemocy fizycznej była przez autorów adresowana do biskupów (1Tm 3,3; Tt 1,7), jednak można ją również przypisywać 
Kolejnym kluczem mogłoby być umiejscowienie „tablicy małżeńskiej” w całym liście Piotrowym. Wedle Janusza Kręcidły, Pierwszy List Piotra jest zbiorem pouczeń, wpisanym „w formę hellenistycznego listu". ${ }^{19}$ Rzeczywiście, wskazuje na to budowa pisma - na wstępie $(1,1-2)$ znajdują się bowiem superscriptio (informacja o nadawcy), adscriptio (określenie adresatów) oraz salutatio (pozdrowienie wstępne), na końcu zaś pozdrowienia $(5,12-14) .{ }^{20}$ Właściwą treść listu J. Kręcidło dzieli na: „,przypomnienie błogosławieństwa Boga Ojca”, które spłynęło na odbiorców listu dzięki zbawczemu dziełu Chrystusa (1,3-12), pouczenia dla wszystkich $(1,13-5,11)$, w tym: pouczenia dotyczące postawy chrześcijan w cywilnej i rodzinnej społeczności pogańskiej $(2,11-3,12)$ oraz zachęta do wytrwałości z pouczeniami dla starszych i młodzieńców $(4,12-5,11){ }^{21}$ Stopień ogólności tej struktury $^{22}$ wskazuje na pewien fenomen listu, który odróżnia go od pism Pawłowych - trudno o określenie precyzyjnych jednostek listu, ponieważ znaczenie każdego z wersetów, nawet gdy wydaje się on luźno związany z treściami bezpośrednio mu towarzyszącymi, uzależnione jest od elementów poprzedzających i następujących silniej niż w innych listach. ${ }^{23} \mathrm{~W}$ przypadku ,tablicy małżeńskiej” nie należy więc zaniedbać tekstu o poddaniu niewolników (2,18nn.) oraz zachęty do wytrwałości we wrogim środowisku (3,8-12).

W Pawłowej tradycji piśmienniczej kluczem do zrozumienia tego fragmentu często bywa jego struktura wewnętrzna - tak jest choćby

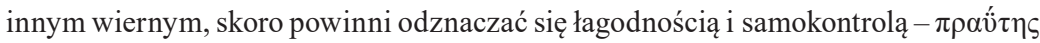
$\dot{\varepsilon} \gamma \kappa \rho \alpha ́ \tau \varepsilon 1 \alpha(\mathrm{Ga} 5,23)$.

19 J. K r ę c id ło, Pouczenia dla wybranych grup adresatów w Pierwszym Liście Piotra, w: M. B a s i u k, A. M a 1 i n a (red.), „Będziecie Moimi świadkami”. Księga Pamiątkowa dla Księdza Józefa Kozyry Profesora Uniwersytetu Śląskiego w 65. rocznice urodzin, Warszawa 2012, s. 190.

20 Zob. S. H a ł a s, Pierwszy List św. Piotra, s. 53.

${ }_{21}$ J. K r ę c i dło, Pouczenia dla wybranych grup adresatów w Pierwszym Liście Piotra, s. 190.

22 Choć niektórzy egzegeci opisują ją nader szczegółowo, np. R. F e 1 d m e i e r, The First Letter of Peter, 22; S. H a ł a s, Pierwszy List św. Piotra, s. 52-23.

${ }_{23}$ R. F e $1 \mathrm{~d}$ m e i e r, The First Letter of Peter, s. 17. 
w przypadku „tablicy małżeńskiej” z Ef 5,21-33, której koncentryczny układ pomaga w pogłębionej lekturze tekstu, stawiając w jej sercu wymiar sakramentalny i uświęcenie żony (ww. 25-26). ${ }^{24}$ Czy „tablica” Piotrowa ma podobny potencjał kompozycyjny? Nie aż tak misterny i przemyślany, ale jednak pozwalający dostrzec zasadniczy temat, którym jest w pełni świadomie przeżywane podporządkowanie żon

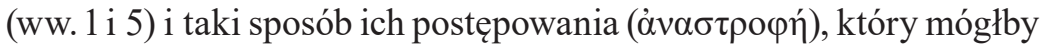
skutkować nawróceniem mężów. Można wedle tego klucza zaproponować następujący podział:

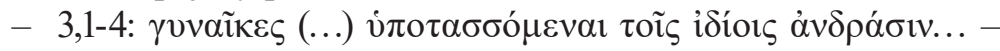
„ozdoby” żon, doprowadzające mężów do wiary;

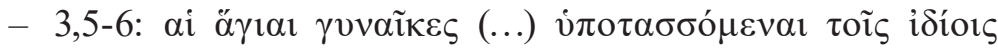

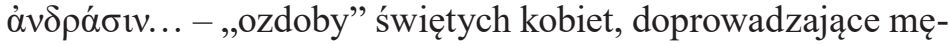
żów do wiary. Przykład Sary;

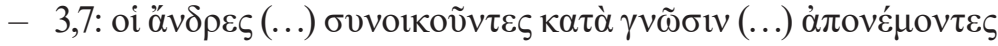
$\tau \mu \eta ̀\rangle$ - świadomość i szacunek okazywany przez mężów.

Tak określone ramy ułatwią uważniejszą analizę tekstu ${ }^{25} \mathrm{i}$ pozwolą wychwycić treści kluczowe - jakimi „narzędziami” (poza oczywistą Bożą asystencją) mogła posłużyć się kobieta, by stać się świadkiem wobec osoby, z którą dzieliła życie, oraz jak mąż mógł wpłynąć na kobietę, przypuszczalnie w związku sine manu, który pragnął jej konwersji na chrześcijaństwo?

\section{Żony jak niewolnicy?}

Swoją „tablicę małżeńską" autor listu Piotrowego otwiera przysłówkiem ó $\mu o i ́ \omega s$, zaznaczając tym samym, że nie sposób zrozumieć

24 A. R a m bi e r t- Kw a śn i e w s k a, ,Kobiety (...) mają być poddane, jak to Prawo nakazuje", s. 71-88; Inne ujęcie struktury, której analiza prowadzi do podobnych wniosków odnaleźć można w: M. K o w a $1 \mathrm{~s} \mathrm{k} \mathrm{i,} \mathrm{Nowe} \mathrm{wino} \mathrm{w} \mathrm{starych}$ buktakach? Analiza socjo-retoryczna Ef 5,21-33, w: A. K u b i ś, K. N a p o r a (red.), Niewiastę dzielna kto znajdzie? (Prz 31,10). Rola kobiet w biblijnej historii zbawienia, Lublin 2016, s. 402-404.

25 Podobną strukturę proponuje G.W. F o r b e s, 1 Peter, Exegetical Guide to the Greek New Testament, Nashville 2014, s. 97. 
jego trudnych, skierowanych do żon pouczeń w oderwaniu od kontekstu poprzedzającego - zaleceń przeznaczonych dla niewolników (1P 2,18-25). ${ }^{26}$ Niektórzy badacze uważają, że przysłówek ó $\mu$ oí $\omega \varsigma$ nie odnosi się do podobieństw w poddaństwie między obiema grupami, argumentując, że pojawia się on również w odniesieniu do mężów, którym wszak poddaństwa względem żon nigdzie się w Piśmie Świętym nie zaleca. Twierdzą, że może on odnosić się do idei poddaństwa in genere, wyrażonej w w. 2,13a słowami: „Bądźcie poddani każdej ludzkiej zwierzchności ze względu na Pana”. Ową generalizację należy uznać za słuszną, biorąc pod uwagę choćby poruszenie tematu poddaństwa również $\mathrm{w}$ w. 5,5, gdzie mowa o poddaniu młodzieńców starszym (przypuszczalnie w znaczeniu starszyzny), nie należy jednak zaprzeczać, że owo poddaństwo, wbrew kontekstowi społecznemu, obejmowało również mężów. ${ }^{27}$

Trudno również zgodzić się ze stwierdzeniem Jana Załęskiego jakoby „nigdzie jednak w Biblii nie ma wskazań, by mężowie byli poddani swoim żonom", ponieważ owo poddanie zostało wyrażone

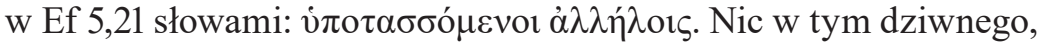

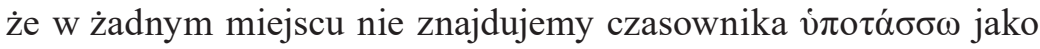
orzeczenia $\alpha \dot{v} \eta ́ \rho$, ponieważ takie stwierdzenie mogłoby wywołać wówczas (czyli w czasach apostolskich) niepotrzebne kontrowersje. Załęski ma jednak rację, mówiąc że słowa Piotrowego pisarza są na tyle trudne, że wielu badaczy zatrzymuje się w pierwszej kolejności nad tym, czego poddaństwo nie oznacza, ${ }^{28}$ nie należy jednak deprecjonować w dyskusji wszystkich głosów, które nie wpływa-

26 Autorzy, np. Sewelys, odżegnują się od porównywania w tym tekście żon do niewolników, mówiąc, że przysłówek ónoí $\varsigma$ podkreśla jedynie, że tematem

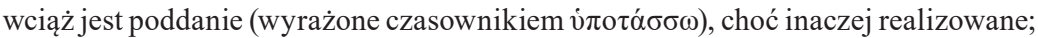
E. G. S e w e ly s, The First Epistle of St. Peter. The Greek Text with Introduction, Notes, and Essays, Grand Rapids 1981, s. 182; zob. D. P. S e n i o r, 1 Peter, w: 1 Peter, Jude and 2 Peter, Sacra Pagina Series 15, Collegeville 2003, s. 81; G. Ch. M ü 11 e r, Anweisungen fur Eheleute nach der Haustafel des ersten Petrusbrief (1 Petr 3,1-7), Studia nad Rodziną 16/2012, s. 37.

27 Zob. D. P. S e n i o r, 1 Peter, s. 81.

28 J. Z a ł ę s k i, Obraz kobiety w listach Nowego Testamentu, s. 242. 
jąc na autorytet Pisma próbują szukać różnych dróg interpretacji stwierdzeń co bardziej kontrowersyjnych. Należy w pierwszej kolejności poczynić ukłon w kierunku autorów nowotestamentowych, w tym autora Listu do Efezjan oraz Pierwszego Listu Piotra, którzy stosują pewien wybieg, omawiając za pomocą innych czasowników

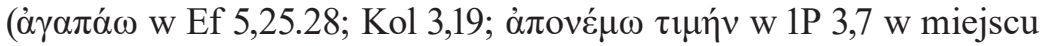

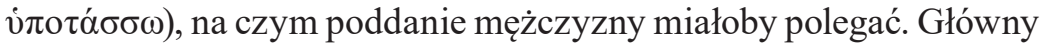
problem tkwi w tym przypadku w analogii mężczyzna-Chrystus, kobieta-Kościół, którą silnie odcisnął w języku teologii fragment Ef 5,21-33 stanowiący poniekąd kontynuację analogii Oblubienica-Jerozolima/naród wybrany, Oblubieniec-Bóg. Mówienie w tym kontekście o mężu językiem „poddaństwa” mogłoby mieć zatem zbyt daleko posunięte konsekwencje teologiczne. Dlatego pozwolę sobie na pewną metodologiczną uwagę, która inspirowana jest intertekstualnym podejściem do interpretacji. Zakładam bowiem, że pierwotni odbiorcy tekstu (wspólnoty całej Azji Mniejszej, głównie wschodniej), którzy przynależeli do wspólnot założonych przez Pawła lub pozostawali pod jego silnym wpływem, ${ }^{29}$ znali również Pawłowy pogląd na małżeństwo i z tej perspektywy byli w stanie spojrzeć na pouczenia Piotrowe skierowane do nich w innych, przypuszczalnie znacznie trudniejszych, czasach wrogości albo nawet prześladowań. Rozumienie Piotrowego „poddaństwa” mężów przez pryzmat bezwa-

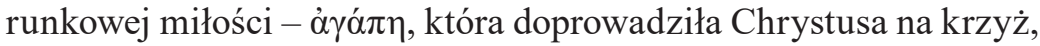
wydaje się w tym przypadku nie tyle właściwe, ile konieczne. ${ }^{30}$

Bez wątpienia kontrowersje budzi fakt, że autor listu wspomina w bezpośrednim kontekście poprzedzającym o poddaństwie niewolników (2,18-21a) i żon (3,1-6), rozdzielając je motywacją uzasadniającą cierpienia w kluczu chrystologicznym (2,21b-25). Choć status obu tych grup - niewolników i żon - był zgoła inny, obie częstokroć spotykał podobnie przykry los naznaczony cierpieniem i przemocą.

29 Zob. D. P. S e n i o r, 1 Peter, s. 8;

30 Zob. więcej w A. R a m b i e r t - K w a ś n i e w s k a, , Kobiety (...) mają być poddane, jak to Prawo nakazuje”, s. 71-88. 
O ile przemoc względem pierwszych była spowodowana ich niewolą, ${ }^{31}$ o tyle wobec drugich znajdowała w Rzymie swoje uzasadnienie już na poziomie mito-historycznym. ${ }^{32} \mathrm{~W}$ tekście Piotrowym różnica zachodzi również na poziomie motywacji - podporządkowanie niewolników jest realizacją „Bożej woli”, podporządkowanie żon służy szerzeniu Dobrej Nowiny. ${ }^{33}$ Choć żona w czasach Pierwszego Listu Piotra nie była już poddana prawu życia i śmierci, ${ }^{34} \mathrm{które} \mathrm{spoczywało}$ wcześniej w rękach paterfamilias, wciąż jako słabsza i fizycznie, i społecznie, narażona była na przemoc - zwłaszcza gdy stawiała

31 Niewolnicy stanowili własność pana, kapitał, którym można było obracać sprzedawać, oddawać w zastaw oraz, oczywiście, wyzwalać. Niewolników karano niekiedy za najdrobniejsze wykroczenia oraz za zapominanie o obowiązkach, ale nadmierne wobec nich okrucieństwo uważano za ,przejaw nieograniczonej brutalności nowobogackiego parweniusza. Do wymierzania kary stosowano kij lub sandał"; L. S c h u m a c h e r, Niewolnictwo antyczne. Dzień powszedni i los niewolnych, tłum. B. M r o z e w i c z, Poznań 2005, s. 261-263; więcej o przemocy wobec niewolników, sposobach ich pozyskiwania, traktowania/eksploatacji i karania w Rzymie zob. N. L e n s k i, Violence and the Roman Slave, w: W. R i e s s, G. G. F a g a n (red.), The Topography of Violence in the Greco-Roman World, Ann Arbor 2016, s. 275-278. Warto wspomnieć również o istnieniu niewolników wiodących godne i twórcze życie, jak Tiron, zasłużony sekretarz Cycerona, który był mu bardziej przyjacielem niż niewolnikiem, dlatego też doczekał się wyzwolenia.

32 Szerzej omawia ów problem Serena Witzke, analizując problem na płaszczyźnie mitologii (nawet mityczni założyciele Rzymu, Romulus i Remus, zostali poczęci w wyniku gwałtu, o który ich matka, Rea Sylvia, oskarżyła boga Marsa), rzymskiego prawa oraz przywołując liczne przykłady literackie, poświadczające skalę zjawiska w rzymskim społeczeństwie, zarówno w rzeczywistości republiki jak i imperium; S. W i t z k e, Violence against Women in Ancient Rome. Ideology versus Reality, w: W. R i e s s, G. G. F a g a n (red.), The Topography of Violence in the Greco-Roman World, s. 250nn.

33 Por. J. Z a łę s k i, Obraz kobiety w listach Nowego Testamentu, s. 244.

34 Chodzi o małżeństwa, w których kobieta przechodziła z potestas ojca do manus męża. Warto wspomnieć, że mąż nie mógł dokonać żonobójstwa bezkarniejej wina musiała zostać uprzednio potwierdzona przez społeczeństwo. Ostatecznie prawo życia i śmierci, nawet w przypadku złapania niewiernej żony in flagranti, zniosły ustawy cesarza Augusta lex Julia de maritandis z 18 r. przed Chr. oraz lex Julia de Adulteriis coercendis z 17 r. przed Chr.; S. W it z k e, Violence against Women in Ancient Rome, s. 254-256. 
sobie za cel przyprowadzenie męża do Chrystusa w sytuacji, gdy chrześcijaństwo było religią niedozwoloną. Nie można więc zaprzeczyć, że choć pobrzmiewa w tablicy Piotrowej Pawłowe „nie ma już mężczyzny ani kobiety, wszyscy bowiem jesteście kimś jednym w Chrystusie Jezusie" (Ga 3,28), które wyraża się w wyraźnym wskazaniu celu kobiecego poddaństwa, tekst nawiązuje do panujących w czasach rzymskich realiów społecznych. ${ }^{35}$

Jak zatem owo kobiece poddaństwo ma oddziaływać na mężów? W pierwszej kolejności zastanawiać może fakt, że żona może wpły-

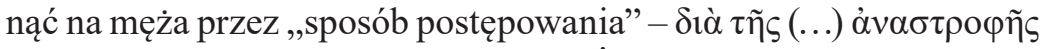

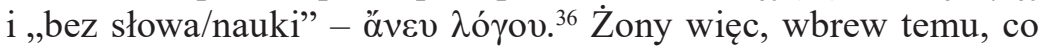
twierdził Paweł, że „wiara rodzi się ze słuchania” (Rz 10,14-17), pozyskiwać miały mężów nie słowami, lecz czynami. Wziąwszy pod uwagę, że słowa te autor listu kieruje do kobiet anatolijskich, klucza do ich zrozumienia doszukiwać się można z jednej strony w Pawłowych zakazach: „Nauczać zaś kobiecie nie pozwalam” (1Tm 2,12) oraz $\mathrm{w}$ - skierowanym tym razem do mieszkanek Grecji: „Kobiety w Kościołach niech milczą" (1Kor 14,34), z drugiej - w trudnej sytuacji społecznej. W pierwszym przypadku wzorcowy byłby zakaz milczenia wynikający z niedouczenia kobiet $\mathrm{i}$ ich ulegania wpływom fałszywych nauczycieli. ${ }^{37}$ Skoro z takimi problemami borykały się mieszkanki Efezu, być może dotyczyły one również kobiet w innych częściach Anatolii. Bardziej prawdopodobny wydaje się jednak drugi

35 Kręcidło dostrzega ten fakt już w samym sposobie zwracania się do kobiet, który nie od początku jest bezpośredni - w pierwszym zdaniu $(3,1)$ autor posłu-

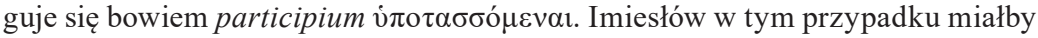
wskazywać na ugruntowanie kobiecego poddaństwa w czasach, w których powstał 1P; J. K r ę c i d ł o, Pouczenia dla wybranych grup adresatów w Pierwszym Liście Piotra, s. 195.

36 Donald P. Senior dostrzega w tym miejscu zabawę słowną- mężczyzna, który nie słuchał „słowa” miałby również zostać pozyskany „bez słowa”; D. P. S e n i o r, 1 Peter, s. 82.

37 A. R a m bi e r t - Kw a ś n i e w s k a, Czego kobietom nie wolno? W poszukiwaniu konsensusu dla interpretacji 1Tm 2,11-15, w: M. S z m a j d z i ń s k i (red.), Gloriam praecedit humilitas (Prz 15,33). Księga pamiatkowa dla Księdza Profesora Antoniego Troniny w 70. rocznicę urodzin, Częstochowa 2015, s. 579-598. 
ze scenariuszy o podłożu historycznym i społecznym. W sytuacji, gdy chrześcijaństwo uznawane było za zagrożenie dla porządku publicznego i w kontekście zalecanej wspólnoty religijnej małżonków, kobiecie głoszącej Dobrą Nowinę mogłoby zagrażać wielkie niebezpieczeństwo. Wobec powyższego, święte postępowanie mogło wydać się autorowi listu nie tylko skuteczniejszą, ale i bezpieczniejszą formą ewangelizacji.

Wiara pogańskich mężów w Pierwszym Liście Piotra miała zatem rodzić się nie ze słuchania, ale z ,przyglądania się, patrzenia” $(\dot{\varepsilon} \pi \circ \pi \tau \varepsilon v ́ \omega ; 3,2),{ }^{38}$ jak to tłumaczą współczesne przekłady biblijne (BT, BSP). Co ciekawe, czasownik غ̇лo $\pi \tau \varepsilon v ́ \omega$, który pojawia się wyłącznie u Piotra, oznacza przede wszystkim „czuwać”, „pilnować”, ale również „osiągać najwyższy stopień wtajemniczenia w misteria". ${ }^{39}$ Termin ów nosi w sobie zatem ideę kontemplacji, wejścia w sacrum, wewnętrznej przemiany. Obserwowanie ,świętego stylu życia”

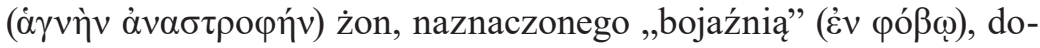
celowo powinno wywołać wewnętrzny zachwyt prowadzący mężczyznę do nawrócenia. ${ }^{40}$ Autor uwydatnia ten fakt, zestawiając ze sobą to, co czyni pięknym zewnętrznie - pięknem złudnym, z tym, co upiększa wewnętrznie: ${ }^{41}$

38 W tym miejscu nie można mieć już żadnych wątpliwości co do pogańskiej tożsamości mężów z „tablicy małżeńskiej”, ponieważ autor tym samym czasownikiem posługuje się w w. 2,12, pouczając: „Postępowanie wasze wśród pogan [غ̇v

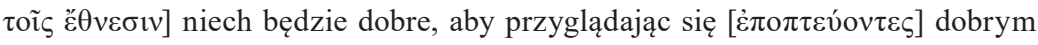
uczynkom...”.

39 LSJ, s. 676; G. W. H. L a m p e (red.), A Patristic Greek Lexicon, Oxford 1995, s. 541.

40 „O przypatrywaniu się” wspomina autor również w w. 2,12, skierowanym do wszystkich chrześcijan, za BT: „Postępowanie wasze wśród pogan niech będzie

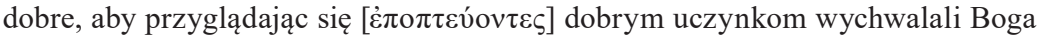
w dniu nawiedzenia za to, czym oczerniają was jako złoczyńców"; zob. S. H a ł a s, Pierwszy List św. Piotra, s. 223.

${ }_{41}$ Treści zawarte w tabeli nie są paralelne, dotyczy to zwłaszcza ostatniej pary, dlatego oznaczenie w postaci *. Takie ich zaprezentowanie pozwala jednak na klarowniejsze wskazanie zawartej w ww. 3-4 antytezy, której obecność podkreślają

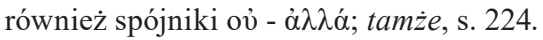




\begin{tabular}{|c|c|}
\hline $\begin{array}{l}\text { ó «̌ } \xi \omega \theta \varepsilon v \\
- \text { „to, co zewnętrzne’42 }\end{array}$ & $\begin{array}{l}\text { ó } \kappa \rho v \pi \tau \text { ò } \varsigma \tau \tilde{\eta} \varsigma \kappa \alpha \rho \delta i ́ \alpha \varsigma \\
\text { - wewnętrzne usposobienie }\end{array}$ \\
\hline 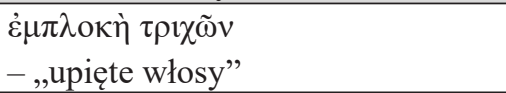 & 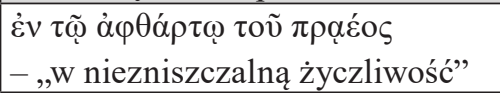 \\
\hline 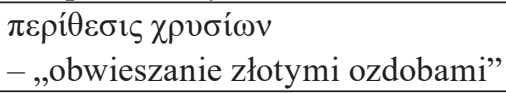 & $\begin{array}{l}\dot{\eta} \sigma \hat{\chi} \chi 10 v \pi v \varepsilon \tilde{u} \mu \alpha \\
-, \text {,tagodny duch" }\end{array}$ \\
\hline 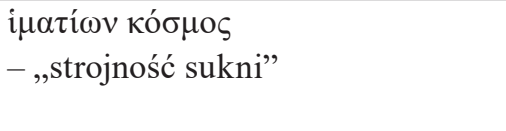 & 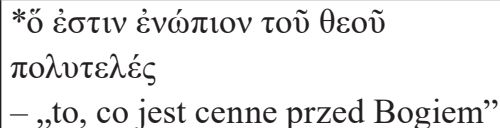 \\
\hline
\end{tabular}

Droga do nawrócenia męża nie wiedzie zatem przez ufryzowanie włosów, ale przez „niezniszczalną życzliwość”, którą D. Senior wydaje się słusznie identyfikować z wewnętrzną kondycją/usposobieniem chrześcijanina, uwidacznianą w decyzjach i determinacji ${ }^{43} \mathrm{Nie}$ doprowadzi do niego również upiększanie się złotymi ozdobami, ale raczej „łagodność ducha”, ta sama, o której wspomina Jezus w swych błogosławieństwach (Mt 5,5). Strojenie się w ozdobne szaty, które stanowią zwieńczenie zewnętrznego piękna, również nie doprowadzi

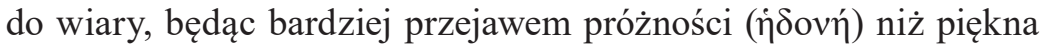
wewnętrznego, zaprzeczeniem tego wszystkiego, ,co jest cenne przed Bogiem”. Kobieca „niezniszczalna życzliwość” i „łagodność ducha”

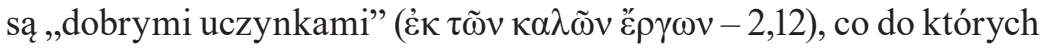
autor wyraża przekonanie, że mogą prowadzić do konwersji z pogaństwa. Ponadto, wobec zakazu nauczania podczas zgromadzeń, milcząca życzliwość i zgodność jawią się jako najskuteczniejsza forma kobiecego świadectwa.

42 Müller rozpatruje te trzy elementy „strojenia się” w kategoriach epitomy opisującej niewieścią naturę, która źle pożytkuje swój kobiecy potencjał; zob. G. Ch. M ü 11 e r, Anweisungen fur Eheleute nach der Haustafel des ersten Petrusbrief (1 Petr 3,1-7), s. 39nn.

43 D. P. S e n i o r, 1 Peter, s. 82. 


\section{Sara przykładem podporządkowania?}

Autor Pierwszego Listu Piotra subtelnie wplata w swą argumentację wątki i historie starotestamentowe, podkreślając w ten sposób, że istnieje ciągłość między Izraelem a pogańskimi Kościołami w Azji Mniejszej. ${ }^{44}$ Czyni tak również w omawianej tablicy, posługując się przykładem Sary, jako podporządkowanej kobiety z dawnych czasów. Ilustrując swe pouczenia takim obrazem, autor wprowadza niemałe zamieszanie, tym mocniejsze, że jak sam twierdzi, „Sara była posłuszna Abrahamowi, nazywając go panem" (1P 3,6). Mamy wystarczające przesłanki przemawiające zarówno za tym, że słowa autora są retoryczną wycieczką, jak i za tym, że należy je rozumieć literalnie.

W pierwszym przypadku przykład Sary może mieć następujące implikacje - żony mają być poddane, ale nie tak definitywnym ,poddaniem", jakiego wymagało od nich prawo rzymskie czy łacińscy i greccy literaci oraz filozofowie epoki cesarstwa. Z czego płynie ten wniosek? Księga Rodzaju przywołuje zaledwie jedną sytuację, w której Sara nazywa Abrahama „panem” (w LXXRdz 18,12). Wziąwszy pod uwagę, że czyni to w scenie, gdy bawi ją fakt możliwości

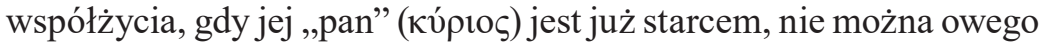
tytułu uznać za dowód poddaństwa Sary. Co więcej, Pięcioksiąg nigdzie nie wspomina o poddaniu Sary, ale aż trzykrotnie mówi o poddaniu Abrahama wobec Sary (Rdz 16,2.6; 21,12)! ${ }^{45}$ Zapomina się również, że tytuł „pan” bardziej niż poddaństwo implikował szacunek względem adresata. ${ }^{46}$ Próbując bronić poddania, niektórzy z badaczy odwołują się do scen, w których Abraham nakazuje Sarze, by przedstawiała się jako jego siostra. Jej zgoda, która obejmowała

44 C. R e e d e r, 1 Peter 3:1-6, s. 537; G. F o r b e s, Children of Sarah. Interpreting 1 Peter 3,6b, Bulletin for Biblical Research 15(2005) nr 1, s. 106-109.

45 K. H. J o be s, 1 Peter, s. 205.

46 A.B. S pence r, Peter's Pedagogical Method in 1 Peter 3:6, Bulletin for Biblical Research 10 (2000) nr 1, s. 117. 
również przykre konsekwencje, ze współżyciem wbrew własnej woli włącznie, miałaby być wyrazem bezgranicznego poddania mężowi. ${ }^{47}$

Rodzi się więc pytanie, czy sceny z Księgi Rodzaju wystarczą, by uznać Sarę za pożądany wzór dla żydowskich i chrześcijańskich żon? Właściwej odpowiedzi nie sposób odnaleźć w liście Piotrowym, ale można ją wywnioskować z szerszego kontekstu. Zilustrowanie wywodu przykładem Sary zostawia kwestię poddania żon na tyle otwartą, by sprzeciwić się literalnemu odczytaniu tekstu, które skłonić może kobiety do niesłusznego znoszenia cierpień. Spencer zauważa ponadto, że błędem poznawczym jest skoncentrowanie się na tym, co kobieta musi, zamiast na tym, co chce. Spojrzenie na Sarę we wszystkich z wymienionych powyżej kontekstów pozwala dostrzec, że „kluczem do poddaństwa” Sary nie jest bezwzględne posłuszeństwo, ale wolny wybór. Spencer zakłada spojrzenie na Sarę w kluczu chrystologicznym - mogła sprzeciwić się Abrahamowi i nie podawać się za jego siostrę, oszczędzając sobie przykrości, postanowiła jednak ocalić męża, stawiając własną przyszłość pod znakiem zapytania. ${ }^{48}$ Poszukiwanie, w tym kontekście, właściwego tekstu z Księgi Rodzaju, do którego odwoływał się autor 1P 3,6 staje się daremne.

\section{Męski szacunek}

Autor Pierwszego Listu Piotra prezentuje odmienne postawy żony i męża, które w prozie życia prowadzić mogą do nawrócenia jednego z małżonków. Działanie kobiet streszcza się w 3,1-2 w codziennym świętym postępowaniu i poddaniu, mężów zaś w ich stosunku względem żon. Egzegeci, zastanawiając się nad poddaniem, stawiają pytania o to, czy dotyczyło ono również uniżenia mężczyzny względem żony. Z perspektywy czysto społecznej i kulturowej negatywna odpowiedź wydaje się oczywista, a skoro tak, jak wyjaśnić

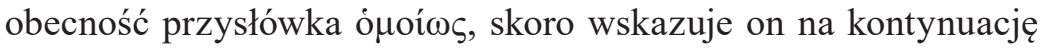

47 C. R e e d e r, 1 Peter 3:1-6, s. 529.

48 A.B. S p e n c e r, Peter's Pedagogical Method in 1 Peter 3:6, s. 118-119. 
tematu poddania, oraz do czego go odnieść? Możliwości są trzy: bądź do poddania in genere w kluczu 1P 2,12-13, bądź do wpływu (często siłowego) męża na konwersję żony, do czego miałby prawo jako głowa rodziny lub też do znoszenia cierpień na wzór Chrystusa, który zostawił doskonały wzór postępowania (2,20-21), przy jednoczesnym niezmuszaniu nikogo do wiary. ${ }^{49}$ Wybór ostatniej wersji wydaje się najbliższy chrześcijańskiemu poszanowaniu wolności, ale zakłada poddaństwo męża, które nie jest jednak explicite wspomniane w omawianym tekście:

Adresaci listu - vं

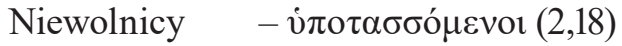

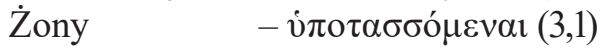

[Kobiety $\quad-\dot{v} \pi$ - $\tau \alpha \sigma \sigma o ́ \mu \varepsilon v \alpha l(3,5)]$

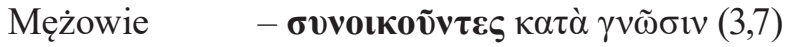

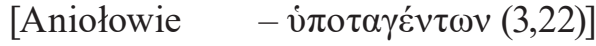

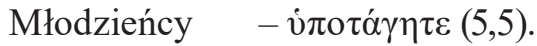

Jak wyjaśnić to terminologiczne odstępstwo? Przypuszczalnie przez zdrowy rozsądek autora listu, który nie chciał zaburzyć porządku społecznego i narażać i tak już zagrożonych chrześcijan nie tylko na kłopoty, ale i na śmieszność - wielu spośród czcicieli bóstw pogańskich oraz filozofów dobrze znało „tablice domowe”. Na pewno nie możemy wnioskować o niekonsekwencji autora, który z pewnością tak dobrał słowa (pozostając, oczywiście, pod natchnieniem), by porządku nie zaburzyć, ale również dosadnie pouczyć. Jakimi formami ewangelizacji mógł posłużyć się chrześcijański mężczyzna pozostający w związku małżeńskim z poganką? Autor listu ujmuje pouczenia względem mężów, posługując się dwoma paralelizmami zwieńczonymi klauzurą:

49 Zob. P. H. D a v i d s, The First Epistle of Peter, NICNT, Grand Rapids 1990, s. $121-122$. 


\begin{tabular}{|c|c|}
\hline 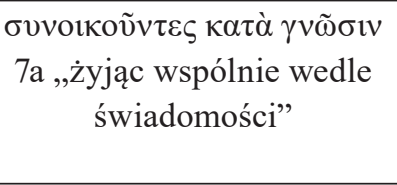 & 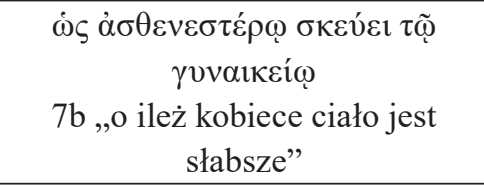 \\
\hline 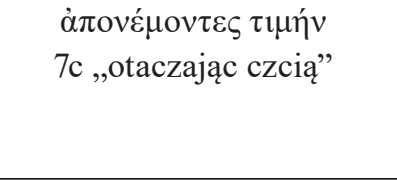 & 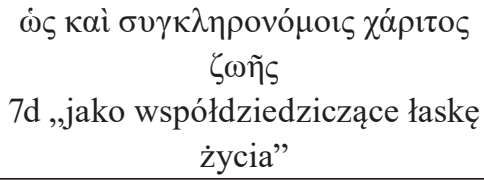 \\
\hline
\end{tabular}

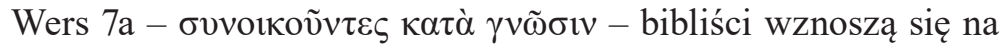
wyżyny pomysłowości, próbując oddać sens tego zwrotu. W BT znajdziemy przekład: „we wspólnym pożyciu liczcie się rozumnie”, BSP: „bądźcie wyrozumiali w waszym pożyciu”, w przekładzie R. Popowskiego: ,przebywajcie (...) w świadomości”; BE: „żyjąc wspólnie" itd. Pierwszy człon owego nakazu, czasownik бvvoıké $\omega$, wedle J. Ramseya Michaelsa, należy w kontekście małżeństwa rozumieć jako wspólne mieszkanie/życie w wymiarze zarówno społecznym, jak i seksualnym. ${ }^{50}$ John H. Elliott proponuje czytanie literalne owego czasownika jako „tworzyć dom [oĩ i wiąże go ze wspomnianymi wcześniej niewolnikami, których au-

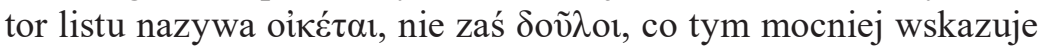
na instytucjonalność całego oĩko oraz nadanie „tablicy domowej” wartości normatywnej..$^{51}$ Interesujące spostrzeżenie czyni Reeder,

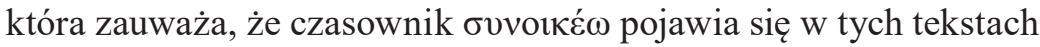
biblijnych, w których sytuacja kobiety nie rysuje się w pięknych barwach - od Rdz 20,3 po 1P 3,7.52 Taki kontekst literacki implikuje obecność problemów w pożyciu małżonków, nieuporządkowania,

50 Zob. też tamże, s. 122.

51 J. H. E 11 i o t t, 1 Peter, s. 575.

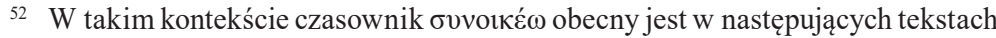
LXX: Rdz 20,3; Pwt 22,13; 24,1; 25,5; Sdz 14,20; 1Ezd 8,67; 2 Mch 1,14; Syr 25,16; 42,9-10. Inne: Mdr 7,28; Syr 25,8; Iz 62,5. W NT tylko w omawianym liście: 1P 3,7. 
z którym mężczyzna powinien sobie poradzić przez określony, naznaczony mądrością sposób, nie zaś przezwyciężać je, wykorzystując swą uprzywilejowaną sytuację fizyczną i społeczną. ${ }^{53}$

Michaels podkreśla również, że nie należy bagatelizować zna-

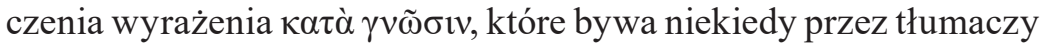
pomijane. Wskazanie na „wiedzę, poznanie” podkreśla bowiem fakt, że wspólne życie mężczyzny z kobietą nie ogranicza się wyłącznie do sfery seksualnej (jak np. w Rdz 4,1). „Poznanie” u Piotra jest bowiem pojęciem na wskroś chrześcijańskim i nawiązuje do wzrastania we wszelkich cnotach (zob. 2P 3,18). Z drugiej jednak strony trudno zgodzić się z Michaelsem, co do innego rozumienia „poznania”. Zasugerowane bowiem przez Reickego tłumaczenie ,ze zrozumieniem” (,z miłością"), w którym pobrzmiewa Pawłowa idea $\gamma v \tilde{\omega} \sigma ı \varsigma$ (na podstawie 1 Kor 8,1-13), jest bowiem równie prawdopodobne. ${ }^{54}$ Dlaczego? Dlatego, że odbiorcy listu pozostawali zapewne pod silnym wpływem Apostoła Narodów, a ich rozumienia słów pisarza Piotrowego nie

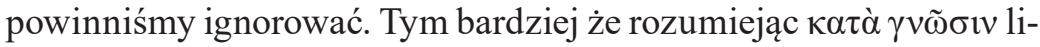
teralnie, jako ,zgodnie z wiedzą/poznaniem”, ${ }^{55}$ moglibyśmy dostrzec wyrażone implicite wskazanie na znaną już wspólnotom anatolijskim od Pawła naukę o małżeństwie (Ef 5,21-33; 1Kor 7,1-5; 10-16), ogólnie wyrażoną w Starym Testamencie słowami Syracha wspominającego „o szczęśliwym, co mieszka z żoną rozumną” (Syr 25,8) oraz o wzajemnej więzi męża i żony $(25,1) .{ }^{56}$

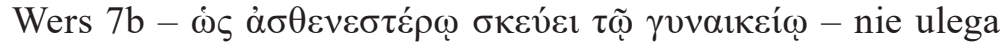
wątpliwości, że ciało kobiece uchodzi w za słabsze, co nie jest

53 C. R e e d e r, 1 Peter 3:1-6, s. 535.

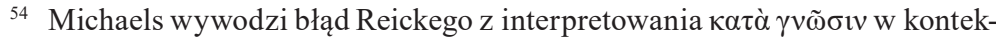
ście wezwania do okazywania żonom szacunku; J. R. M i c h a e 1 s, 1 Peter, Word Biblical Commentary 49, Waco 1988, s. 168.

55 Podobny przekład ,according to knowledge” proponuje Karen H. Jobes w swoim komentarzu do 1P; zob. K. H. J o b e s, 1 Peter, s. 207.

$56 \mathrm{~W}$ takim przypadku moglibyśmy mówić o wyrażonej implicite wzajemności; zob. J. H. E 11 i o t t, 1 Peter, s. 575-576. 
spostrzeżeniem wielce przełomowym, ${ }^{57}$ ale implikuje fakt, że autor listu ma wiedzę co do tego, że nie zawsze mężowie odnosili się do kobiecego ciała z należytym szacunkiem. Przymiotnik ả $\sigma \theta \varepsilon v \eta ́ s$ użyty w stopniu wyższym wymaga przedmiotu lub osoby, z którą „kobiece ${ }^{58}$ ciało” a raczej „kobiece naczynie” mogłoby zostać porównane. Nietrudno jednak wywnioskować, że chodzi o ciało mężczyzny/ męża, w którego naturę wpisana jest właściwa mężczyźnie tężyzna. Inną kwestią była znaczna różnica wieku małżonków, ponieważ wedle zwyczaju dojrzali, ponad 30-letni mężczyźni, brali za żony dziewczęta zaraz po osiągnięciu przez nie dojrzałości, którą choćby w Palestynie wyznaczano na 12. rok życia. Inną interesującą kwestią

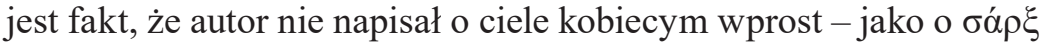
czy $\sigma \tilde{\omega} \mu \alpha$ - ale posłużył się enigmatycznym rzeczownikiem $\sigma \kappa \varepsilon v ̃ o \varsigma$, który w języku Septuaginty określa raczej przedmioty, sprzęty domowe, militarne i kultyczne (zob. np. Rdz 24, 53; Wj 3,22; Kpł 6,21; Lb 1,50; Pwt 1,41; Joz 7,11; Sdz 9,54; Rt 2,9; 1Sm 6,8 itd.) oraz elementy odzieży noszone na ciele. ${ }^{59}$ Również w Nowym Testamencie dominuje podobne znaczenie. Śladem autora Piotrowego podąża jedynie Paweł, ale tylko w 1Tes 4,4, implicite ewentualnie w 2Tm 2,21. Uznanie ciała

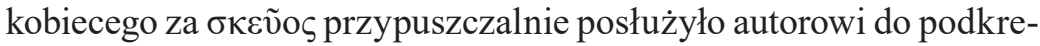

57 Elliot uważa je za konwencjonalne, podkreślając, że jest to spostrzeżenie typowo męskie, dając tym samym wyraz własnym poglądom i perspektywie, z której komentuje list Piotrowy. Choć jego krytyce starożytnych przekonań odnośnie do kobiecej natury należy przyklasnąć, gdyż hipokratejskie „męskie (nasienie) jest silniejsze niż żeńskie" (Corp. hipp. Gen. 6,1) nie znajduje odbicia w rzeczywistości, to jednak nie należy zapominać, że przekonania z naszego punktu widzenia antykobiece były wśród starożytnych powszechne, a ich przyczyn nie należy upatrywać w męskim seksizmie, ale w ustroju społeczeństwa. Kobieca słabość fizyczna, moralna, intelektualna podkreślana była przez wielu: m.in. Platona, Owidiusza, List Arysteasza, Muzoniusza Rufusa itd.; J. H. E 11 i o t, s. 576; I. M. L o n i e, The Hippocratic Treatises "On Generation", "On the Nature of the Child", "Diseases IV”, Berlin-New York 1981, s. 128.

58 Przymiotnik ten jest hapax legomenon w całym NT.

59 T. M u r a o k a, A Greek-English Lexicon, s. 623-624. Być może to właśnie znaczenie należałoby wiązać z jednostką i pośrednio jej ciałem, skoro ubiór wskazywał na osobę - jej pochodzenie i status społeczny. 
ślenia kruchości fizycznej kobiety. Trudno zgodzić się z Hałasem, że jest to nawiązanie do opisu stworzenia człowieka z gliny ( $\mathrm{Rdz} 2,7)$, które trudno byłoby w tym kontekście uzasadnić. ${ }^{60}$ Kluczem jest natomiast kolejne pouczenie względem mężczyzn.

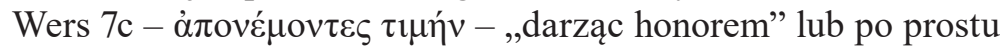
„okazując szacunek” mężczyzna troszczy się o słabszą kobiecą naturę. Zgodzić się można z Elliotem, że wezwanie to jest paralelą względem

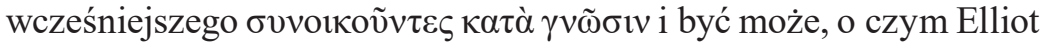

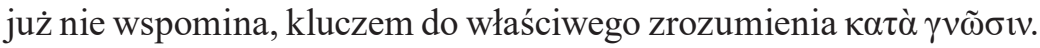
Skoro bowiem rozumne życie mężów z żonami zakłada okazywanie ${ }^{61}$ tym drugim szacunku, ${ }^{62}$ coś musi stać u podstaw owej rozumności. Szacunek wśród małżonków chrześcijańskich oraz w małżeństwach mieszanych nie był niczym wyjątkowym, o czym wnioskować można na podstawie źródeł, ale wpisywał się w antropologiczny koncept

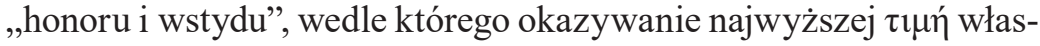
nej żonie było sprawą fundamentalną, gwarantem społecznego ładu. Żona na szacunek musiała zasłużyć swą skromnością i wiernością (Xen. Oec. 7,42; 9,11). Pod wyrażeniem ,zgodnie z rozumem” można więc, być może, rozumieć „wedle obowiązującego ładu społecznego”.

Czym różniłaby się zatem owa $\tau \iota \mu$ małżonków pogańskich od $\tau$ $\mu$ męeżów chrześcijańskich? Odpowiedź na to pytanie pobrzmiewa najpierw w w. 2,7 oraz w dalszej części omawianego wersetu 3,7. W w. 2,7 zapisał autor: „Wam zatem, którzy wierzycie, cześć [ $\tau 1 \mu \eta ́]$ !”, co oznacza, że źródłem szacunku jest wiara w Chrystusa. W tym drugim przypadku kluczem jest motywacja, którą jest wspólne

60 S. H a ł a s, Pierwszy List św. Piotra, s. 230.

${ }^{61}$ Czasownik ảmové $\mu \omega$ jest hapax legomenon. Pojawia się jednak w podobnych znaczeniach u Ojców Kościoła i pisarzy wczesnochrześcijańskich (1 Clem. 1,3); J. H. E 11 i ot t, 1 Peter, s. 579. Pod pojęciem tym rozumie się „przyznać”, „wydzielić dział"; J. S t ro ng, Grecko-polski słownik Stronga z lokalizacją słów greckich i kodami Popowskiego, tłum. A. C z w oj d r a k, Warszawa 2015, s. 92; zob. G. W. H. L a m p e (red.), A Patristic Greek Lexicon, s. 202.

${ }^{62}$ Ewolucję pojęcia $\tau \imath \mu$ od rozumienia materialistycznego do etycznego zwięźle

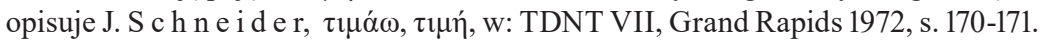


dziedziczenie tej samej łaski życia, ${ }^{63}$ co jest konsekwencją wiary, o której mowa w 2,7.

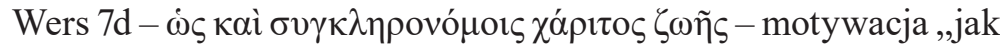
współdziedziczącym łaskę życia" jest paralelą do omówionej powyżej

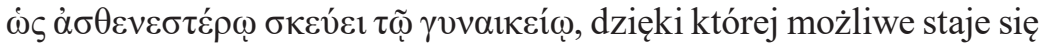
odkrycie jej pełnego sensu. Autor podkreślił bowiem, że ciało kobiece jest słabsze, a więc i bardziej narażone na uszczerbek - zwłaszcza gdy na kobiecie wymusza się praktykowanie tej samej religii, którą kultywuje jej małżonek wraz z jego rodziną. ${ }^{64} \mathrm{U}$ podstaw szacunku wobec kobiety nie leży jednak jej fizyczna słabość, ale równość w dziedziczeniu „łaski życia”. ${ }^{65}$ Uczynienie z kobiety współdziedzica życia jest novum w całym Nowym Testamencie. Jak dalekie mogą być tego konsekwencje? Z pewnością nie tak dalekie, jak te, które głoszą badaczki feministyczne, twierdząc, że tekst Piotrowy traktuje o równości kobiet względem mężczyzn. ${ }^{66}$ Dobrze streszcza ten fakt Elliott, mówiąc, że „afirmacja jedności w Chrystusie nie może być mylona z ustanawianiem równości społecznej" i porównując jedność w Chrystusie z relacjami między dziećmi i rodzicami, którzy na płaszczyźnie społecznej i relacyjnej nie są równymi partnerami, ${ }^{67}$ choć, dodajmy, cieszą się tą samą ludzką godnością. O tym, jak trudna była ta nauka dla odbiorców starożytnych i średniowiecznych, świadczy wielość lekcji tego krótkiego wersetu. ${ }^{68}$ Nietrudno się dziwić ingerencjom w tekst, ponieważ tym podobne przejawy nobilitacji kobiecej natury

63 J. H. E 11 i o t, 1 Peter, s. 578-579.

64 Por. C. R e e d e r, 1 Peter 3:1-6, s. 526.

$65 \mathrm{Z}$ dużym prawdopodobieństwem można stwierdzić, że chodzi o łaskę życia wiecznego, wedle słów z w. 1,4: „Do dziedzictwa niezniszczalnego i niepokalanego, i niewiędnącego, które jest zachowane dla was w niebie”; J. K r ę c i d ł o, Pouczenia dla wybranych grup adresatów w Pierwszym Liście Piotra, s. 198-199.

${ }^{66}$ Zob. S. D ow d, 1 Peter, w: C. A. N e w s o m, S. H. R ing e (red.), The Women's Bible Commentary, London-Louisville 1992, s. 371.

67 J. H. E 11 i o t, 1 Peter, s. 580.

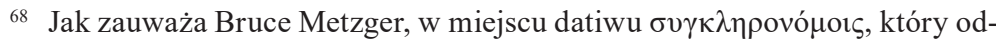
nosi się do żon, w niektórych manuskryptach widnieje nominatiw $\sigma v \gamma \kappa \lambda \eta \rho o v o ́ \mu o r$, który wskazywałby na mężów. Zarówno struktura tekstu, jak i jego przesłanie przemawiają za datiwem, co tym mocniej uwidacznia niechęć niektórych kopistów 
nie miały większego przełożenia na zmianę sytuacji kobiet - czy to społecznej, czy politycznej.

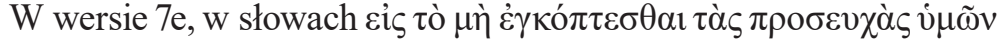
wyrażona została zasadność uprzednich pouczeń skierowanych do chrześcijańskich mężów. Przypuszczać należy, że ową klauzurę należy odnieść nie tylko do w. 7, ale również do uprzednich ww. 1-6. Modlitwa zależna jest od jakości relacji - by była niezakłócona, wymaga zgodnego pożycia rodziny. Pouczenia autora Piotrowego prezentują grupę przeszkód, które wśród chrześcijan azjatyckich mogły być szczególnie dojmujące. Kręcidło zauważa w tym miejscu, że pouczenia zawarte w „tablicy małżeńskiej” stanowią uszczegółowienie „,szerszej nowotestamentowej zasady, według której złe relacje z bliźnimi utrudniają lub uniemożliwiają modlitwę (zob. np. Mt 5,23; Mk 11,5)" ${ }^{69}$

\section{Czy Piotr i Paweł mówią jednym głosem?}

Między nauką Pawła i Piotra o małżeństwie zachodzą wyraźne różnice, jednak ich odmienność nie wpływa na zaistnienie jakiejkolwiek światopoglądowej czy teologicznej sprzeczności.

Po pierwsze - tym, co odróżnia tzw. tablice małżeńskie w przekazie Pawłowym (Ef 5,21-33) i Piotrowym (1P 3,1-7) jest z pewnością kontekst historyczny, w którym powstały. O ile bowiem w Liście do Efezjan nie znajdujemy żadnych przesłanek przemawiających za tym, że na chrześcijaństwo czyhało realne zagrożenie, ${ }^{70}$ o tyle w liście Piotrowym bez trudu odnaleźć można teksty wskazujące na prześladowania. ${ }^{71}$ Sytuacja legalności i delegalizacji chrześcijaństwa miała przypuszczalnie wpływ na wydźwięk tablic.

dla tym podobnych treści; B. M. M e t z g e r, A Textual Commentary on the Greek New Testament, Stuttgart 1975, s. 691.

${ }^{69}$ J. K r ę c i d ło, Pouczenia dla wybranych grup adresatów w Pierwszym Liście Piotra, s. 199.

70 Świadczy o tym charakter listu, który poświęcony jest zagadnieniom teologicznym, przede wszystkim chrystologii, oraz moralnym (z Haustafeln).

${ }^{71}$ Nie będziemy odwoływać się przy tym do okoliczności i czasu powstania, ponieważ są one wątpliwe i w obu przypadkach intensywnie dyskutowane. 
Po drugie - odmienni są również odbiorcy tekstu - o ile Paweł zwraca się do małżeństw chrześcijańskich, o tyle Piotr omawia problem małżeństw mieszanych.

Po trzecie - różnicę dostrzec można w proporcjach - w tablicy efeskiej dominują pouczenia dla mężczyzn (5,25-33a), w Piotrowej pouczenia skierowane są przede wszystkim do żon (3,1-6).

Po czwarte - dostrzeżona dysproporcja ilościowa ma również przełożenie na treść, ponieważ o ile w Liście do Efezjan mężczyzn wzywa się do doskonałej miłości, àyó $\pi \eta$, tożsamej z tą, którą Chrystus ukochał Kościół (5,25), o tyle do podobnej miłości, choć nienazwanej wprost - tym razem jednak na wzór Sary - wezwane zostały chrześcijańskie żony w sytuacji zagrożenia przemocą $(3,6)$.

Po piąte - skoro w obu tekstach zauważyć można wezwanie do podobnej miłości, co ze współmałżonkami? Otóż w Liście do Efezjan do żon apeluje się, by darzyły męża szacunkiem graniczącym z bojaźnią należną Chrystusowi, w liście Piotra mężom nakazuje się okazywać cześć właściwą kobiecie zamężnej. Choć autor Pawłowy posłużył się czasownikiem $\varphi$ oß́́ $(5,33)$, Piotrowy zaś rzeczowni-

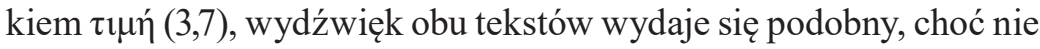
identyczny, bowiem w pierwszym przypadku mamy do czynienia z szacunkiem okazywanym chrześcijańskiemu współmałżonkowi, w drugim - pogańskiej żonie.

Po szóste - wspólną osią jest w końcu cel pouczeń skierowanych do mężów i żon. W przypadku „tablicy małżeńskiej” w Liście do Efezjan miłość męża prowadzi do uświęcenia żony (5,25-26), w tablicy Piotrowej miłość żony owocuje ,pozyskaniem” męża, czyli jego nawróceniem. Efektem finalnym w obu przypadkach ma być osiągnięcie życia wiecznego.

Z powyższego wynika, że choć obie tablice małżeńskie diametralnie się różnią, w swym zasadniczym przesłaniu są podobne i możliwe do ujęcia w jedno zdanie: małżeństwo - czy to chrześcijańskie, czy mieszane, z jednym chrześcijańskim współmałżonkiem - jest formą wspólnego ziemskiego życia ukierunkowaną na osiągnięcie wieczności z Chrystusem. 


\section{Jak odczytywać ,tablicę małżeńską” w liście Piotrowym?}

Caryn Reeder streszcza trzy propozycje interpretacji tego kłopotliwego passusu Piotra, zaś jako czwartą podaje własną. Nim pokusimy się o własną syntezę, warto pokrótce przytoczyć przywoływane przez Reeder wykładnie:

- Pierwsza z propozycji polega na uznaniu sprzeczności passusu z przesłaniem Pisma Świętego in genere, zwłaszcza w kontekście wielu tekstów, które nawołują do otaczania opieką najsłabszych oraz krytykują tych, którzy wykorzystują swoją władzę i autorytet, by krzywdzić innych (Pwt 15,12-18; 24,14-22 ; Iz 3,13-15 itd.).

- Druga uznaje tekst za niemal idolatryczny, uważając, że jest on adaptacją przekonań panujących w imperium rzymskich, a więc aplikuje do małżeństw chrześcijańskich typowo pogański model rodziny wraz z właściwym relacjom poddaństwem. Takie przekonanie reprezentują badaczki feministyczne pokroju Jennifer G. Bird. Jak słusznie zauważa Reeder, tym podobne przekonania pozbawiają Pismo Święte autorytetu, stawiając ponad nim przekonania jego czytelników.

- Trzeci polega na wyartykułowaniu w 1P 3 definitywnego zakazu przemocy domowej w w. 7, który został skierowany do mężczyzn. Poddanie i rezygnacja $\mathrm{z}$ dóbr materialnych jest $\mathrm{w}$ tej wizji działaniem intencjonalnym, które, z jednej strony, miało ustrzec kobietę przed ewentualną krytyką czy prześladowaniem, z drugiej, miało zaimponować mężczyźnie. Przedstawicielka tego poglądu, Catherine Clark Kroeger, podkreśla, że małżeństwo sine manu pozwalało kobiecie na praktykowanie odmiennej religii, co jednocześnie ograniczało możliwość zaistnienia sytuacji przemocowej. Kroeger interpretuje tekst Piotrowy przez pryzmat Pawłowego wezwania do wzajemnego poddaństwa z Ef 3,21. Reeder dostrzega słabe strony tej interpretacji, piętnując $\mathrm{u}$ autorki nieznajomość źródeł, które dowodzą powszechności zjawiska przemocy wobec kobiet w I w. po Chr. oraz podkreśla, że małżeństwa sine manu umożliwiały 
nieprzyjęcie rodzinnych tradycji religijnych męża, ale nie miały zastosowania wobec kultów publicznych, których nierespektowanie mogło być surowo karane.

- Sama Reeder uznaje aktualność tekstu, interpretując go w kontekście faktycznie istniejącego problemu przemocy wobec kobiet w I w. po Chr. i współcześnie. Czyni to, odwołując się do trudnej sytuacji chrześcijan żyjących w pogańskich społecznościach miejskich i wśród pogańskich członków rodziny. Zalecane żonie poddaństwo i łagodność mogły, wedle Reeder, służyć przekonaniu społeczeństwa i rodziny, że chrześcijaństwo nie jest realnym zagrożeniem dla społecznego ładu. Tekst jest aplikowany właśnie w środowiskach, w których chrześcijaństwo postrzegane jest jako szkodliwe, i choć Reeder, jak sama twierdzi, nie miałaby śmiałości wezwać zagrożonych przemocą chrześcijanek do poddaństwa, mogłaby jednak przynieść im pocieszenie, przyrównując ich cierpienie do cierpień Chrystusa. Bezwzględne poddaństwo kobiet nie jest więc głównym przesłaniem 1P 3,1-7.72

Choć propozycja Caryn Reeder wydaje się wielce trafna, domaga się jednak pozytywnego dopowiedzenia opartego na spostrzeżeniach Aìdy B. Spencer. Żony (jak i niewolnicy w rozdz. 2) są w relacji małżeńskiej, zwłaszcza w takiej, która naznaczona jest przemocą, typem cierpiącego Chrystusa. Zważywszy na to, że małżeństwo sine manu pozwalało kobiecie na odejście od brutalnego męża $\mathrm{a}^{73}$ oraz powrót na łono własnej rodziny, pozostanie przy mężu ze względu na jego nawrócenie i zbawienie było/jest heroicznym aktem wolnej woli, dalece idącym poświęceniem powodowanym chrześcijańską miłością. W tym kontekście przesłanie tablicy małżeńskiej 1P 3,1-7 jest aktualne. Nie należy postrzegać jej więc w kategoriach przymusu do podporządkowania krzywdzicielowi, gdy w grę wchodzi realne zagrożenie zdrowia czy życia.

72 C. Re e d e r, 1 Peter 3:1-6, s. 531-534.

73 Umożliwiał to również tzw. przywilej Pawłowy, choć explicite pozwala na odejście strony niewierzącej (1Kor 7,15). 
Piotrowa „tablica małżeńska” może zostać uznana za uzupełnienie Pawłowej nauki o małżeństwie. Doskonale realizuje ona ideę wzajemnego podporządkowania, zaprezentowaną w Ef 5,21-33, będąc niejako odpowiedzią na ogromne wymagania, które stawia autor przed mężami w Efezie. O ile bowiem w korespondencji z Efezjanami mężowie zostali wezwani do miłości bezgranicznej względem żon na

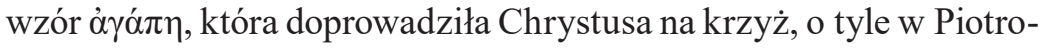
wym liście do mieszkańców Azji Mniejszej przynaglane są do niej kobiety - ale tylko w bardzo specyficznym kontekście, gdy chrześcijaństwo uznawane jest za zagrożenie dla publicznego ładu. Skąd pewność, że chodzi o, tym razem, kobiecą àyó $\Uparrow \eta$ ? Ponieważ żadna inna miłość nie jest w stanie skłonić osoby od całkowitej rezygnacji z siebie, gdy na horyzoncie tli się nadzieja na zbawienie bliźniego. Adresatki Piotrowych słów wzywane są, na wzór Sary, do niesienia

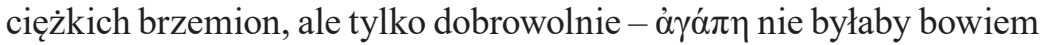
doskonałą miłością, gdyby rządził nią przymus. „Tablica małżeńska” w Pierwszym Liście Piotra interpretowana w innym kluczu może stać się realnym zagrożeniem dla rodzin, które borykają się z problemem przemocy. Pamiętać powinni o tym przede wszystkim duszpasterze, przed którymi często staje trudne zadanie wyjaśniania kłopotliwych tekstów Pisma Świętego wiernym.

\section{Anna RAMBIERT-KWAŚNIEWSKA}

Słowa kluczowe: przemoc domowa, małżeństwa mieszane, tablica domowa, 1P 3,1-7, poddanie żony

Keywords: domestic violence, mixed marriages, household code, 1 Pe 3,1-7, submission of wife

\section{Mixed marriages and how to deal with them according to the "Marriage Table" in 1 Peter 3,1-7. For or against St Paul's Tradition?}

Summary

When looked at from the modern reader's perspective, the "Marriage Table", which is one of the elements of the so-called Haustafeln (household 
codes), is a quite difficult passage. This is more so since there are a few of them in the New Testament (Eph 5,22-6,9; Col 3,18-4,1; Tit 2,1-10 and 1 Pet $2,13-3,7)$. The main difficulty that one encounters while reading them is that they stress a lower status of women, expressed in the idea of "subjection". The "Marriage Table" in 1 Pet 3,1-7, which is examined in the article, adds two aspects to the aforementioned interpretational problem: the religious diversity of spouses (mixed marriages) and, following it, violence. Numerous preachers accept a literal interpretation of the text, arguing that a woman in a marriage with an aggressive husband should endure the violence. A contextual and intertextual reading, however, leads us to discover that the heroic act of sacrifice for the sake of the husband's conversion is not obligatory, but should be treated as an act of free will. Therefore a woman's voluntary submission as well as her being a victim of aggression for a greater good can subscribe to an idea of agape which Paul mentions in the "Marriage Table" of Eph 5,21-33. 